Full Length Article

\title{
Engaging universe 4.0: The case for forming a public relations-strategic intelligence hybrid
}

\author{
Alba Santa Soriano ${ }^{a, *}$, Rosa María Torres Valdés ${ }^{b}$ \\ ${ }^{a}$ Technology Transfer Office, University of Alicante, San Vicente del Raspeig, Alicante, 03690, Spain \\ ${ }^{\mathrm{b}}$ Departament of Communication and Social Psychology, University of Alicante, San Vicente del Raspeig, Alicante, 03690, Spain
}

\section{A R T I C L E I N F O}

\section{Keywords:}

Public relations

Strategic intelligence

Universe 4.0

Disruption

Engagement

Hybridity

\begin{abstract}
A B S T R A C T
In this article we follow a range of significant academics, practitioners and policy makers in highlighting the need to engage with the disruptive digital transformation of the fourth industrial revolution. Often called universe 4.0, this is an economy based on data that dilutes, in an unprecedented fashion, the boundaries between the physical, biological and digital world in all spheres of society. In having to face up to the uncertainty, complexity and speed associated with this global challenge, organisations of all kinds will be impelled to rethink future skills, jobs and business models. We focus on how this uncertain situation affects public relations. We suggest that the resulting paradoxes and controversies become an opportunity to research and reflect on the past and present of our discipline and redirect attention to the processes, strategies, and tools of intervention required for improved contemporary and future effectiveness. This present study analyses universe 4.0 processes affecting both the practice and the social function of public relations and argues for close linkages with multidimensional strategic intelligences and disruptive technologies based on artificial intelligence. It also involves conducting exploratory qualitative research based on a bibliometric analysis of specialised literature; undertaking content analysis via computational linguistics techniques; and applying Delphi methodology to consider public relations in universe 4.0. Our findings suggest not only that strategic intelligence is under researched in our field, but that a more developed public relations intelligence capable of adapting to universe 4.0 needs to be a hybrid of existing public relations and contemporary strategic intelligence.
\end{abstract}

\section{Introduction}

Different agents (e.g., international entities, technologists and expert commentators) use the term universe 4.0 to capture the idea of a fourth industrial revolution (Wilkesmann \& Wilkesmann, 2018). In their accounts, universe 4.0 , by enabling a new era of unprecedented transformations (Wolf, Semm, \& Erfurth, 2018), transcends conventional accounts of the impact of the introduction of large-scale information and communication technologies (Schmidt \& Cohen, 2013). This notion of 4.0 refers to the current environment in which disruptive technologies and trends, such as new computational capabilities, artificial intelligence, the Internet of things, advanced materials or neuro-technologies (Kuteynikov, Izhaev, Lebedev, \& Zenin, 2019), are already driving transformative changes in the way we live, work or relate to one another (World Economic Forum, 2017). While we reject any simplistic technological determinism account, we consider that this disruptive notion of 4.0 has catalysing effects on organisations who have little option, if they are to remain viable, other than to integrate these technologies into a new generation of more efficient, agile and sustainable management systems. We readily acknowledge, however, that this notion of 4.0 is not without controversy and it aligns us with another account of an increasingly complex, uncertain and changing context (see, e.g., McKie \& Heath, 2016; Prescott, 2012). Indeed, there is a growing consensus that global challenges are changing how all kinds of organisations interact with their environment, and the result is an increasing requirement for anticipation, influence and intelligence to guarantee survival (Arcos, 2016; Salminen, Ruohomaa, \& Kantola, 2017). We conclude that, under these circumstances, relational management becomes a key success factor even in conditions that are sometimes characterized, as if people did not matter, as the data economy (Eggensperger \& Redcross, 2018; Jiménez, 2016) and that public relations, albeit a public relations augmented by strategic intelligence, has a significant role to play.

\footnotetext{
* Corresponding author.

E-mail addresses: alba.santa@ua.es (A. Santa Soriano), rosa.torres@ua.es (R.M. Torres Valdés).
} 


\section{Literature review}

In this section, we conduct a conceptual review of the keywords on which this research is based. The aim is to present a theoretical corpus that allows exploring the role of a hybrid Public Relations augmented by strategic intelligence in this uncertain, disruptive and transdisciplinary scenario (Roper \& Hurst, 2019).

In this sense, the reviewed literature reflects a certain interdisciplinary approach between Public Relations and Intelligence, proposing concepts such as "Public Relations Intelligence", defined by Arcos (2016: 269) as "the need for specific expert knowledge and intelligence on strategic communication and relationship management", of interest to our research in the framework of disruptive processes and universe 4.0. For this reason, we subdivided the theoretical framework of reference into three sub-headings: one dedicated to the contextualisation of universe 4.0, and two others focusing on the recent conceptualisation of public relations and strategic intelligence, respectively, including a critical perspective.

\subsection{Universe 4.0}

In the context of 4.0, disruption leads to the emergence of new ideas and requires public relations professionals to innovate in order to adapt to global challenges (Ahmad, 2019). As Kuteynikov et al. (2019) commented, the challenge for public relations is complex and impossible to ignore, leading to in-depth discussions, due both to theoretical and normative implications. According to these authors, in the context of this fourth technological revolution, public relations, with "the emergence of unprecedented new ways of human interaction with technical means (...) can potentially be divided into three categories" (2019: 3966): coexistence, where subjects of relations in their own right coexist, and they can be both people or technical means (for example, smart assistants that automate customer relations); relationships, where a technical tool's actions are subordinated to a person's will in order to meet individual needs in specific areas (e.g. virtual tools that take advantage of the potential of big data to improve message segmentation and automation), and mergers, where digital and mechanical elements are fully integrated into a biological subject (for example, cyborgs). The theoretical and legal implications of this public relations proposal lead these authors to conclude that it is urgent "to develop regulatory frameworks able to create conditions for the successful introduction of advanced technologies and minimize their negative consequences" (2019: 3964).

In fact, Bachmann (2019) reflects on the moral blindness produced by big data and automation in this scenario, transforming organisations' interactions with their audiences in a context of liquid modernity. Other authors such as Sebastião (2020); Gregory and Halff (2020); Beiner (2019a); Carriço (2018); Valin (2018) or Leonhard (2017) raise the question of the disjunction between technology and humanities, between an economy of intelligent machines and an economy based on cognition and human creativity. These authors thus lead us to reflect on the variables of critical and creative thinking, emotional intelligence and human sensitivity as dimensions that cannot be replaced by automatic processes. The consequence, as explored by Arief and Gustomo (2020), is the imperative need for public relations professionals to become aware of the hybrid nature of universe 4.0, in which human potential can be maximised by technology, while bearing in mind that technologies are created themselves by human beings. These informational challenges arise in the midst of the era of artificial intelligence and cognitive technologies that Davenport (2018) coins under the term Analytics 4.0. They require profound analytical skills of organisational culture, combining internal and external analysis methodologies, organisational resources and, above all, individual staff competences, who understand the distinction: "all AI tools use technology but not all tech is AI" (Valin, 2018: 5).

Indeed, from a cross-disciplinary perspective, it seems reasonable to consider the Public Relations-Strategic Intelligence hybrid as conceptual framework. Numerous studies on the digital economy have focused on understanding the implications of this Universe 4.0. They have addressed multiple aspects such as: competences (Lombardero, 2015; UN, 2019); governance challenges and good practices (Kovacs, 2018; Pedreño, 2017), and the legal challenges that arise (Becerril \& Ortigoza, 2018); as well as others related to the impact on domains such as technological surveillance (Miranda, 2015; San \& Romero, 2016), artificial intelligence (Galloway \& Swiatek, 2018; Maier, Möhring, \& Werkle, 2018; Voosen, 2017) or public relations 4.0 in particular (Torres \& Santa, 2018). While it seems undeniable that universe 4.0 offers a space to develop industrial competitiveness (Camarinha, Fornasiero and Afsarmanes, 2017), the processes to achieve this progress have sparked controversies and criticism, making it necessary to engage in an in-depth reflection (Kovacs, 2018). For example, Navarro and Sabalza (2016: 169) question whether we should approach Industry 4.0 as an evolution or a revolution, given that as the authors explain, "there is no basic scientific or technological revolution, the change arises rather from combining, to a large extent already existing technology, and to innovate in a systematic and lasting way". In addition to the importance of systematisation that characterises intelligence, they draw attention to the absence of key actors in these pilot innovation processes. Other authors, for their part, such as Quintana (2019) propose resorting to philosophical learnings to train innovation management leaders. The objective is to strengthen humanisation within the framework of what the author calls "revolution 4.0", a project that encourages a transdisciplinary dialogue. The present article supports this latter proposition.

\subsection{Public relations}

It seems that ever since globalisation and digital technologies emerged, public relations has been undergoing a constant process of reconfiguration (McKie \& Munshi, 2007), expanding its multifaceted nature (Wiencierz \& Röttger, 2017; Xifra, 2011) and strengthening its permeable and interdisciplinary idiosyncrasy (L'Etang, 2008; Edwards \& Hodges, 2011; McKie, Xifra, \& Lalueza, 2016). And even more so, since the critical and reflexive current emerged, putting forward the need to first understand not only communicative processes, but also the social and organisational context in which they develop. As Heath (2006: 110) synthesised, "public relations is a piece of some whole. The challenge is to continue to search to discover the whole and public relations' place in it".

In this sense, recent academic literature points to an emerging relationship between strategic intelligence and public relations (Santa, Lorenzo, \& Torres, 2018), emphasizing the need to make progress in reconfiguring public relations, using the convergence and reciprocity between both disciplines to face the challenges of the technological revolution (Arcos, 2016; Lim, 2016; Macnamara, 2016b, 2016b; Macnamara \& Zerfass, 2012; McKie \& Heath, 2016; Roper, 2016; Willis, 2016). As Crumpton (2015) argues, the conceptualisation of this intelligence discipline is based on the notion of change, understanding it as "the ability to predict and react faster and more effectively to upcoming changes" (p.12). According to Arcos (2016: 264), this function is essential today for public relations, as it allows addressing the need to offer a "thoughtful organizational response to changing conditions and to address challenges from the environment or from stakeholders" in the technological context. In this sense, works like those of Arief and Gustomo (2020) or Panda, Upadhyay, and Khandelwal, 2019: 14) go one step further by analysing the impact of artificial intelligence on the public relations industry, noting that "some of the grey areas in the application and adoption of AI and the PR industry are yet to be uncovered".

From a critical and reflective perspective, the latest specialised literature delves into the controversies of the impact of these disruptive technologies in the field of communication and public relations. As 
Sebastião (2020) affirms, the functions of communication and public relations are exercised following a professional, ethical and socially responsible philosophy given their ability to build social realities, and to create and share meaning. Thus, these technologies, mostly centred on artificial intelligence, are only useful if they are used to complement and strengthen human capabilities. Otherwise, they can actually do more harm than good. In fact, though applying them to communication management can create opportunities, they are not without risks (Zerfass, Hagelstein, \& Tench, 2020). In this way, risk prevention and need for anticipation become intrinsic to PR intelligence (Arcos, 2016; Roper, 2016), and play a crucial role in the research and analysis phases of the generalised strategic management of public relations.

In this sense, authors such as Gregory (2010) had already put forward the links between intelligence and research and analysis in public relations, advocating the function of "identifying the real issues, problems and opportunities within a specific time and events context" (p. 48) and recommending that PEST and SWOT analyses be part of the strategies of issues management. The latter include typologies of specialised analysis in environmental scanning, which perform combined studies of different dimensions in the environment (political, economic, social and technological for PEST analyses and strengths, weaknesses, opportunities and threats for SWOT analyses) in order to know the positioning of the organisation in relation to its context and reduce decision-making uncertainty (Richardson, 2017). Furthermore, there are also adaptive methodologies, which, over time, have given rise to multiple acronyms such as: PESTEL, PESTLE, PESTLED, STEEPLE, STEPE or SLEPT (Aguilar, 1967; Thompson, 1967; Fahey \& Narayanan, 1986; Morrison, 2007; Perera, 2017). The latter, based on similar postulates (More, Probert, \& Phaal, 2015), have a broader scope and also address legal, ethical and environmental challenges, for example the PESTLE analysis (focused on the political, economic, social, technological, legal and environmental dimensions), STEEPLE (social, technological, economic, ethical, political, legal and environmental) or EPISTLE (economic, political, infrastructure, social, technological, legal and environmental). In short, these are specialised analyses which lie at the heart of strategic intelligence organisational praxis (Fleisher \& Bensoussan, 2007). They have recently been playing a crucial part in responding to the information-communication challenges of our digital age (Harrysson, Métayer Estelle, \& Sarrazin, 2012; Maymand, Shayan, \& Kashani, 2015; Calof, Richards, \& Santilli, 2017; Ahmad, Amirkhani, Ezzat, \& Hozori, 2018). We have some vivid examples in public relations such as those given by Erkul, Yitmen, and Çelik (2016), who point to the analysis of stakeholders using intelligence as a catalyst for stakeholder engagement in high technological-impact collaborative projects. This approach applies to the present study, especially given that intelligence analysis is being completely transformed by the new disruptive technologies supported by this fourth industrial revolution (Heuer \& Pherson, 2015; Fantinelli \& Sivilli, 2015; He, Wu, Yan, Akula, \& Shen, 2015). It is sharing the realities of public relations evolutions conditioned by the technological revolution (Kuteynikov et al., 2019).

Therefore, according to Pereira, Portilla, and Rodríguez (2019), the growth in activity stemming from digital platforms and the explosion of artificial intelligence and big data represent an opportunity for public relations to adapt to the technological context, strengthening the idea of hybridising concepts linked to relations and intelligence. But, as specified by Galloway and Swiatek (2018), one needs to recognise and understand the controversial implications that characterise the complexity, diversity and scope of the multiple uses of artificial intelligence in public relations practice. And, as defended by Falcão, Ramalho, \& Nobre (2020), on must not forget either the capacity for dialogue with stakeholders, thus leading to a three-dimensional application of the notion of intelligence in public relations, based on the activities of: "diagnosing public relations problems", "scanning the business environment" and "meeting with and advising senior management" (p. 3).

Based on these premises, we start with a first conceptual approach to PR intelligence, understood as categorising functions and establishing competent relational processes to develop organisational intelligence. Organisational intelligence, in turn, consists in applying specific techniques to activate permanent systems of engagement with strategic audiences and responsible relations with the community, the lot relating to matters of shared interest. Naturally, this definition is somewhat complex or ambiguous: it represents a challenge which motivated the present study.

We could say that through the hybridization of concepts of public relations and strategic intelligence, we are updating and re-signifying the practice of public relations in the 21 st century, especially in this context of fourth technological revolution, because, based on their initial conceptualisations (Long, 1924), they add value to organisational decision-making. Similarly, the anticipatory function of public relations is not new (Aldrich \& Herker, 1977; Turk, 1986): ever since the 1970s, public relations has developed a consolidated function of conflict prevention and active listening of the environment (Galloway, 2013; Macnamara, 2017; McKie \& Heath, 2016). It has specialised in identifying, analysing and monitoring strategic issues to respond to changes in the environment and manage relations with the public and society in general. The question now is to be able to take advantage, at the rate imposed by universe 4.0, of the systemic, predictive and technological potential of strategic intelligence and incorporate its maxim: "being able to give the right information, to the right people, at the time opportune to make successful decisions" (Porter \& Millar, 1985), as a competitive advantage of the public relations of the future.

\subsection{Strategic intelligence}

Due to its multidimensional nature, strategic intelligence has become an innovation management system (Aguirre, 2015): one that is shaped by a theoretical and normative corpus, based on systematic, distributed and permanent processes of collection, analysis and communication of strategic information in order to take organisational decisions and actions (Choo, 2002; Cohen, 2013; Lim, 2016; McDowell, 2009; Rotolo, Rafols, Hopkins, \& Leydesdorff, 2017; Xu, 2007). Like public relations, the discipline of strategic intelligence is being transformed (López, Otegi, Porto, \& Cobo, 2019), and its conceptual identity also represents a complex phenomenon (Kuosa, 2011), linked to different approaches, scopes and with implications for organisational action (Ahmad et al., 2018). Moreover, in a high-tech context, progress in the discipline is adopting a cross-cultural configuration (Adidam, Gajre, \& Kejriwal, 2009; Capatina, Bleoju, Yamazakib, Amazakib, \& Nistor, 2016). It has thus become an umbrella term in Organisational Intelligence studies (Seitovirta, 2011). In this way, strategic intelligence has turned into a multidimensional concept, by integrating, among other related disciplines: leadership, knowledge management, prospective or artificial intelligence (Aguirre, 2015; Liebowitz, 2006; Maccoby \& Scudder, 2011; Seitovirta, 2011). It is ever more collaborative and social (Degerstedt, 2015), as well as increasingly multidisciplinary (Maymand et al., 2015), relating to issues as strategic today for public relations as engagement, leadership or hybrid threats (Arcos, 2018; Heath, Singh, Ganesh, \& Kroll-Smith, 2013; Maccoby, 2001; Reinsborugh, 2017;).

To summarise, new "surnames" accompany this intelligence perspective, such as "collective intelligence" (Boder, 2006), "marketing intelligence" (Calof, Wright, \& Dishman, 2008), "social media intelligence" (Moe \& Schweidel, 2014), "social intelligence" (Degerstedt, 2015) or "artificial intelligence" (Galloway \& Swiatek, 2018). More holistic terms have even emerged, such as "holistic intelligence" (Macnamara, 2016b) or "disruptive intelligence" (Vriens \& Søilen, 2014), which acknowledge the role of emotion and the value of relationships in organisational decision-making. This variety of terms supports the thesis defended by a critical and reflexive current of public relations regarding the potential of multiple intelligences to reconfigure the discipline once again (McKie et al., 2016). Furthermore, as established by Panda et al. (2019), artificial intelligence is causing a strategic disruption in Public Relations: it is turning into an instrument used to face both today's 
complexity and the uncertainties of organisational strategic management and communication decision-making (Osswald, 2019). Once public relations intelligence is conceptualised, this latter point helps to build the binomial concept of Public Relations-Strategic Intelligence proposed in the present work.

Consequently, in this article, we approach the 4.0 universe as an opportunity to investigate and reflect on the past, present and future of the discipline of public relations. We focus on the disruptive processes affecting both the practice and the social function of public relations, linked to the multidimensional nature of strategic intelligence and the emergence of AI-based disruptive technologies. By centring on these processes, we can explore the combination of management elements that potentially lead to innovating and transforming the praxis in this digital age. To do this, we start with the general objective of analysing these 4.0 universe disruptive processes from a transdisciplinary, critical and constructive perspective. The specific objectives focus on identifying these disruptive processes in public relations praxis and pinpointing transdisciplinary intersections in the disruptive management of public relations. To finish, we determine whether the Public RelationsStrategic Intelligence duality constitutes a feasible, key concept for the future of public relations.

\section{Materials and methods}

This section details the research objectives and the methodology followed to achieve them. The general objective is to analyse the disruptive processes of public relations in universe 4.0 adopting a transdisciplinary, critical and constructive approach. The specific objectives are to detect the disruptive processes affecting public relations practice, to determine transdisciplinary intersections in the disruptive management of public relations and finally, to determine the feasibility of the Public Relations-Strategic Intelligence hybrid as a key concept for the future of public relations. The key elements of our research problem are:

- Intelligence: understood as transforming data into strategic knowledge for decision-making.

- Automation: understood as processes of automation using technology.

- Engagement: understood as participatory multi-actor dialogues and exchanges to foster mutual understanding and to co-create public relations practices and outcomes.

Specifically, the study applies a qualitative methodology, of an exploratory and descriptive nature, developed over three consecutive stages of research described below. The overall aim was to identify and define the constitutive elements of the problem under study.

\subsection{Research questions}

Due to the marked exploratory and descriptive nature of this work, rather that raising starting hypotheses, we set out research questions in order to guide the study towards its objectives (Sampieri, Collado \& Lucio, 2014; Hernández and Mendoza, 2018). These questions were as follow:

1 How does the revolution 4.0 affect the social and practical function of public relations?

2 Which main inter-disciplinary intersections could help to confront the disruptive processes of public relations practice?

3 Does it make sense to establish a hybrid concept between Public Relations and Strategic Intelligence to face the future challenges of public relations?

\subsection{Stages of the study}

The research was sequential and followed three stages: (1) a bibliometric analysis of the specific literature; (2) a linguistic analysis using computational techniques; and (3) the adaptation of the Delphi technique to public relations in universe 4.0. These phases are detailed below.

The first phase consisted of a secondary investigation, based on a systematic review of scientific literature that resulted in a bibliometric analysis. We sought to identify and systematise the scientific information available on public relations and strategic intelligence in the documentary collections of reference, as well as to analyse keyword patterns shared by both disciplines, in order to explore initial relationships and to categorise the emerging study area as a "Public Relations Intelligence" concept. To this end, two specific types of bibliometric analysis were mainly conducted: keyword occurrence frequency and keyword co-occurrence network.

This type of initial bibliometric analysis allows using statistical analysis to examine patterns of scientific production in a specific field, helping in this case to overview the emerging links, keywords and future research fronts between both disciplines (Godin, 2006; Martínez, 2014; Santa et al., 2018). In addition, bibliometric approaches have become increasingly relevant in recent years as they offer a "structured methodology for collecting and processing scientific information to identify trends and the degree of progress of different disciplines (...) and serve as a basis to establish knowledge of the theoretical foundation, its level of evolution, and identify possible contributions to the building of knowledge" (Aguirre, 2015: 102). In the specific case of public relations research, there were some notable examples of interest to this study, such as Míguez, Baamonde, and Corbacho (2014), Castillo and Xifra (2006), Pasadeos and Renfro (1992), Kim, Choi, Reber, and Kim (2011) and Morehouse and Saffer (2018), and in relation to strategic intelligence, research such as that of Aguirre (2015), López et al. (2019) and Madani and Weber (2016).

A specialised documentary corpus of 40 documents was first established. The documents were selected according to the following inclusion criteria: (1) scientific and original information on public relations and strategic intelligence as a specific field of study; (2) published from 2000 to 2016, the time horizon for the analysis; (3) in English; (4) scientific articles of high international impact. The exclusion criteria were as follows: (1) lack of access to the document. The data was extracted from Scopus and the relevant records were selected via manual verification, obtaining a total of 198 matching records using the systematic review technique detailed above.

The second phase focused on analysing the content of specialised literature in both disciplines through computational linguistic techniques. The aim was to identify the disruptive processes object of study by measuring of correlations and generating of vectors between the target concepts of public relations and strategic intelligence, based on co-occurrence statistics. Subsequently, to extend the specialised corpus in both disciplines for computational analysis, a new search and collection of articles was performed in both disciplines, focusing on common themes such as strategy, issue management and technology, concentrating especially on computer tools and the results of the bibliometric analysis. Thus, previous inclusion criteria were extended to: (5) thematic areas related to this approach and (6) scientific articles, reports, books and thesis as a type of document. The data capture also developed the previous two steps, generating a corpus of 423 records to which content analysis was applied through computational linguistic techniques. This latter technique is becoming widespread in related disciplines to explore transdisciplinary approaches (Ha \& Boynton, 2014; Taylor \& Kent, 2010; Jelen, 2017; Xu, Wang, Li, \& Haghighi, 2017). Currently, it represents a "new generation of studies" (Chávez \& Yamamoto, 2014) that is helping to optimise traditional content analysis using a large corpus, and increasing the scope, reliability and agility of the analyses. In addition, by using these kinds of techniques, we are 
making use of artificial intelligence, and specifically Natural Language Processing (NLP), which is based on the computational processing of the semantic meaning of words (Martí, 2018). Specifically, these new analysis techniques combine the traditional theoretical foundation of corpus linguistics and the processing capacity of computational linguistics to interpret the context of specialised languages (Pérez \& Moreno, 2009; Vargas, Almendros, Anke, \& Valdés, 2013).

Given that in this phase, we attempted to analyse the way in which the literature describes the disruptive processes of both the strategic intelligence corpus and the public relations corpus, we prioritised the term "process" to analyse co-occurrences. Indeed, in addition to its accumulated frequency, the term includes research processes, strategic communication management processes to generate trust, automation and anticipation processes, within a broader framework of strategic planning aimed at empowering organisations and stakeholders in their informed decision-making.

The research process was triangulated with the realisation, during the third stage, of a Delphi, aimed at contrasting the results of previous research phases from the perspective of both academic and professional experts. The latter is in line with authors such as Caldiero (2016), who considered that the processes of relational innovation in 4.0 contexts reinforced the need to reconceptualise the concept of Public Relations in this new era. This phase consisted of a qualitative primary study, based on an adaptation of the Delphi technique, which is widespread in public relations (Boynton, 2006; Kent \& Saffer, 2014; Manías, Jin, \& Reber, 2019; Ponti \& Domingo, 2014; Roper \& Hurst, 2019; Wakefield \& Watson, 2014).

The Delphi objective centred on performing a systematic analysis of the public relations concept in universe 4.0 (García \& Suárez, 2013) and, specifically, on identifying trans-disciplinary intersections in the disruptive processes of public relations. The sampling was intentional, non-probabilistic and the criteria to select the experts were as follow: (1) academic, researcher or professional profiles; (2) in areas of knowledge related to Communication, Sociology, Computer Science, Economics, Civil Engineering, Biotechnology and Philosophy; (3) belonging to public or private organisations with some experience in the 4.0 universe; and (4) with public resumes or personal blogs, which included access to specialised publications on the topics of study. We started by providing key informants with an initial definition, which had been accepted by the research team in the previous 4.0 environment research phases, and was used as a basis for the experts to express their opinion, to discuss and to offer their own definition of Economics. 4.0, Technology 4.0, Communication 4.0, Public Relations 4.0, Influence 4.0, Governance 4.0, Local Development 4.0 and Regional Development 4.0. Two dialectical rounds took place. First, all the experts' conceptual and critical responses to the concepts under analysis were collected. After systematising the responses, they were sent to all the participants who had answered in the first round, so they could express their opinion again on the conceptual contributions and seek a satisfactory consensus. The proposal to participate in Delphi was sent to 31 people, of which 17 experts followed the complete procedure. Among them, an additional 5 people said that they did not know how to define 4.0 or relate 4.0 to what was asked of them: Economy 4.0, Technology 4.0, Communication 4.0, Public Relations 4.0. The qualitative content analysis was conducted both manually in a first approach to the collected information, and later using the Atlas.ti 7.0 software to carry out a more in-depth and systematic analysis (Sabariego, Vilà, \& Sandín, 2014). Specifically, a semantic network map and analysis of the common links or co-occurrences between the coded terms under study were elaborated.

In this way, this phase made it possible to build the study's theoretical-conceptual and empirical framework, as well as to identify and systematise data sources for further computational analysis. Specifically, once the study corpus - understood as document collections belonging to each discipline- was created, a linguistic analysis was applied using computational techniques with the aim of identifying the disruptive processes under study by measuring the correlations and generating vectors between target concepts relating to public relations and strategic intelligence, based on co-occurrence statistics.

\section{Results}

The results of this study are presented below, broken down according to each research phase described above:

\subsection{Phase 1: results of the bibliometric analysis}

Based on the bibliometric approach, keyword analyses were used to approximate the articles' central semantic content, based on the concurrence and relevance of keywords in the micro-level corpus. First, the keyword occurrence frequency analysis allowed us to identify the most recurring terms in the articles published until 2016, applying two indicators of thematic associations: occurrence (series 1) and relevance (series 2). Table 1 lists the 10 keywords with the highest occurrence and their degree of relevance in the corpus corresponding to the bibliometric analysis.

Regarding the keywords with the highest frequency of occurrence, "intelligence" had the highest incidence. The term's reiteration points to its use as a general concept-intelligence being understood as a discipline in this case-and to its relationship with its main domain of application-business-due for example to the repetition of terms such as "business" and "business intelligence" (2.05). This data can be related to the ideas that were beginning to gain strength in the academic literature i.e. multiple intelligences in public relations and the transformation itself of strategic intelligence into a multidimensional concept that integrates related disciplines. "Public Relations", for its part, came third, but with a high degree of relevance (1.63). "Model", "system", "data", "need" and "knowledge" were keywords of interest for the subject under study, given their potential semantic associations with the exploration of technological issues and disruptive processes of public relations 4.0.

Subsequently, the keyword co-occurrence network analysis was applied to discover the initial relationships between these most frequently occurring keywords, by connecting the corpus keywords that shared the same incidence both on the basis of occurrence and relevance. This analysis generated a map of relationships between 57 nodes. The results allowed the identification of 4 clearly differentiated semantic clusters and the expansion of the number of keywords under analysis. Fig. 1 illustrates the results:

These clusters further our understanding of the relationships between resulting keywords. Cluster 1, in red, in the lower left area, groups terms such as "model", "customer", "data", "business", "product", "insight", "advantage" or "opportunity", which predominate in Business Intelligence practices. Cluster 2, in green, in the lower right area, focuses on the relationship between "intelligence" and "public relations", grouping terms such as "analysis", "need", "relationship", "challenge", " practice" or "theory", which could represent Public Relations Intelligence attributes. Cluster 3, in blue, in the upper left area, is dominated by terms such as "system", "business intelligence", "CRM", "platform", "software", "technology" or "decision support", which clearly refer to the field of computer technologies as potential elements of information systems. Finally, cluster 4, in yellow and in the upper right area, encompasses terms such as "development", "decision making" and "relational approach", which, together with the CRMs refer to a relationship management and could correspond to the relational dimension of intelligence, both as a stage of the cycle itself ("internal communication") and as a source of information ("market").

Together, these first analyses lead researchers to delve further into the relevant subjects situated between public relations and strategic intelligence, such as processes and technology, especially those oriented towards data, systematisation and computer tool issues. 
Table 1

Frequency of the top keywords related to Public Relations and Intelligence.
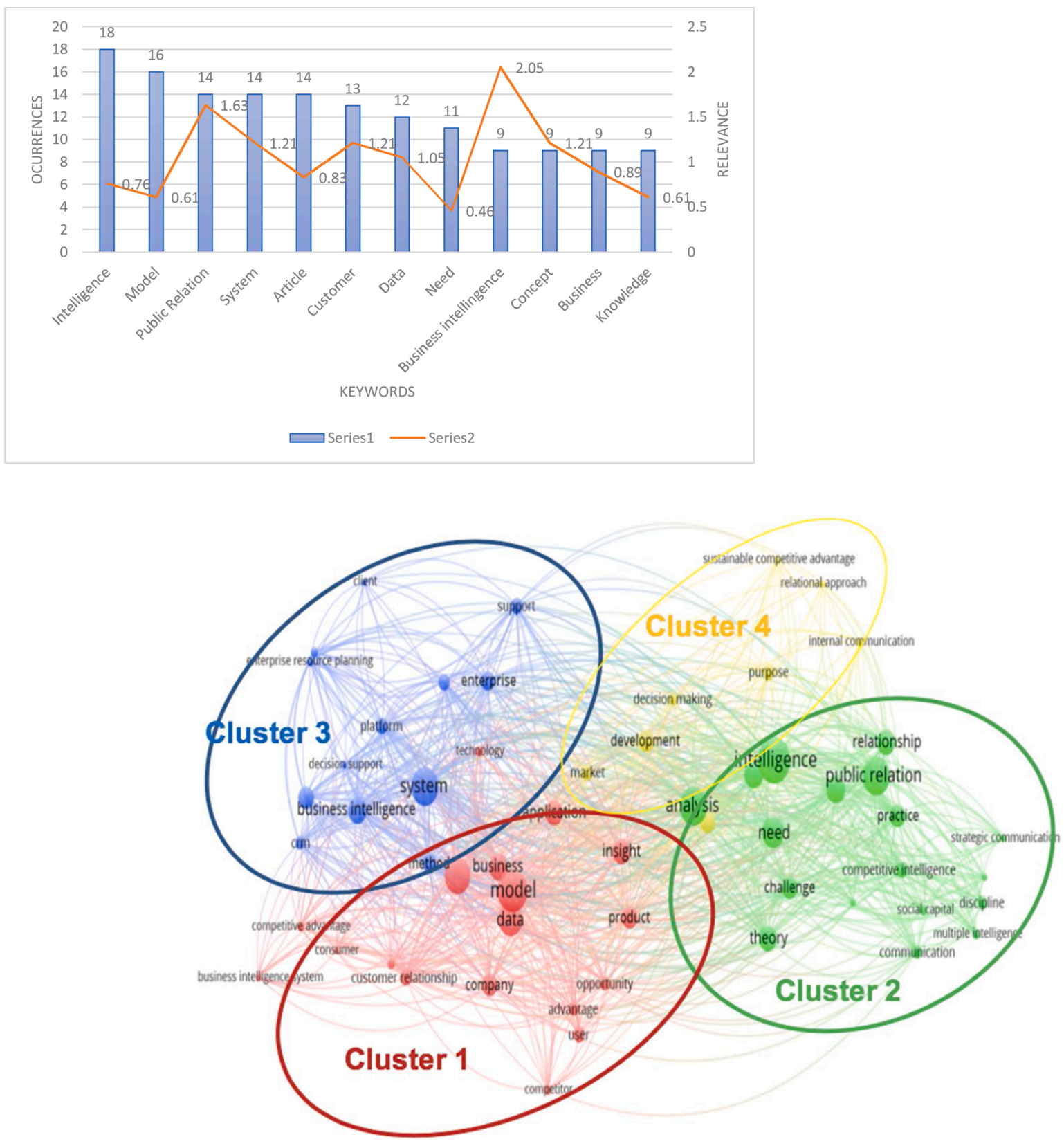

Fig. 1. Keyword co-occurrence network with 57 nodes and the identified clusters.

4.2. Phase 2: results of the content analysis through computational linguistics techniques

Based on a computational approach, the second stage of research focused mainly on three specialised analyses. First, the keywords with the highest absolute frequency in the corpus were analysed, allowing to identify those with the highest incidence between both disciplines. Table 2 lists the 10 keywords with the highest absolute frequency in the corpus:

"Research" was the term with the highest incidence in the corpus, was a significant concept in the praxis of both disciplines, that was also related to the following prominent terms: "information", "management" and "data". The concept of "processes" appears in fifth place, also followed by other relevant ones such as "social media" and "technology", linked to the technological dimension of this work, as well as "trust", an
Table 2

Ranking of keywords according to greatest absolute frequencies.

\begin{tabular}{ll}
\hline Keywords & Absolute frequencies \\
\hline Research & 14,019 \\
Information & 12,994 \\
Management & 8928 \\
Data & 8303 \\
Process & 5637 \\
Analysis & 5468 \\
Innovation & 4746 \\
Social_media & 4616 \\
Technology & 3897 \\
Trust & 3194 \\
\hline
\end{tabular}


essential goal of public relations.

Next, to explore the term "processes" semantically, a co-occurrence analysis was conducted. It allows detecting the terms with which these processes can be associated in relation to their meaning. Specifically, the co-occurrence analysis enables us to identify the most repeated words in the same sentence in which the analysed term appears and to know its semantic relationships. Table 3 illustrates the 10 keywords of the corpus presenting the highest co-occurrence with the term "processes":

"Engagement", "intelligence" and "tools" stand out as the three terms with the highest incidence in the phrases where the term "processes" appears. A fact that leads us to consider them as processes of high interest for this study. They were followed by other recurring terms in the previous analyses such as "information", "research", "management", "analysis" and "innovation", which continue to be highly meaningful in relation to the potential binomial relationship between Public Relations and Strategic Intelligence.

Finally, to further explore the semantic meaning of the three keywords presenting the highest co-occurrence with the term "processes", an analysis of their vectors was conducted. Vectors represent the quantitative relational representations of the meaning of the corpus terms and they allow identifying the words used for similar purposes, helping to reflect on their relationships based on the obtained objective degree of similarity between them obtained. Thus, a vector represents each word making up a vector space, composed in this work by the series of 10 words most associated with each other. Each vector is calculated via the cosine, producing a value between 0 and 1 , where a greater proximity to 1 expresses a greater degree of similarity between terms (Martí, 2018). Table 4 illustrates the ranked series of the most relevant keywords for each analysed term.

First, worthy of note is the affinity of the term "engagement" with "interactivity" and "dialogic" with maximum values of similarity. Next, "engagement" appears associated with terms referring to notions of common good such as "public organisations" and "public engagement", strongly related to the social function of public relations. Finally, the term "engagement" has a strong relationship with what we could describe as a potential and sequential chain of impact management in the building of links in public relations. This management reflects growing techniques and strategies oriented towards the involvement, participation and empowerment of actors within "organization public relationships". Furthermore, the term is linked to anticipation, a basic principle of strategic intelligence.

With respect to "intelligence" itself as a potential disruptive process in public relations, "value-added" stands out as the most similar term in the entire table, followed by other relevant terms such as "decision", "strategic planning", "threats "," up-to-date ". The latter partly reflect the essence of the strategic intelligence discipline itself, insofar as they refer to the need to be up to date to make informed decisions that allow to reduce risks and anticipate future changes, pointing out the role of "tools" and "process" in its management, and highlighting examples such as "analytics", "gathering" and "disseminates". Together, they refer to the essence of the intelligence cycle processes, focusing on the collection,

Table 3

Ranking of keywords presenting the greatest cooccurrence with the term "processes".

\begin{tabular}{ll}
\hline Keywords & Co-occurrence \\
\hline Engagement & 1838 \\
Intelligence & 1078 \\
Tools & 954 \\
Information & 915 \\
Research & 615 \\
Management & 583 \\
Communication & 455 \\
Analysis & 411 \\
Strategic & 404 \\
Innovation & 399 \\
\hline
\end{tabular}

analysis and communication of strategic and crucial information to construct public relations' anticipation capacity in the 4.0 universe.

Finally, the analysis of the vector space of the term "tools" produces a large part of the terms semantically associated with technology as a tool. First, it highlights "algorithms" as the main term with the greatest similarity, followed by others such as "computer-based applications", "apis", "algorithmic" or "automated". Thus, taking into account the technological and critical interest of this work, as well as the futuristic character of the relationship between public relations and intelligence, we decided to examine further the semantic meaning associated with two relevant terms from that perspective: "automation" and "anticipation." Table 5 illustrates the ranked series of most relevant keywords for each concept:

"Automation" has strong links with universe 4. 0 concepts and new trends in artificial intelligence, such as "newest", "data-intensive" or "bia", which refer to attributes of a data and information intensive economy in real time. In addition, the meaning of "anticipation" is more closely related to the critical current of public relations, insofar as it is linked to more reflexive, inclusive, strategic and decisive issues. Worthy of note is its similarity with terms such as "reflection", which even reached the maximum value of the entire study, as well as "inclusion", "governance" and "responsiveness", among others. Nevertheless, both concepts complement each other based on the systematic review of specialised literature.

\subsection{Phase 3: Delphi results of experts on universe 4.0 regarding its conceptual delimitations and processed by Atlas.ti}

As specified above, the proposal to participate in Delphi was sent to 31 people, among which 17 experts followed the full procedure. Fig. 2 illustrates the vision of these experts concerning the conceptual delimitations as well as the connections between the terms analysed. Overall, a semantic network of phenomenological association and causal links or relationships of belonging was obtained:

Based on this figure, the experts signalled that the technological disruption affecting current and future practice of public relations stems from the economic field: Economy 4.0. This Economy 4.0 is directly associated with Technology 4.0, in turn associated with Communication 4.0. In addition, experts attribute Communication 4.0 to the need for new ways of communicating in the new economy, which gives rise to Public Relations 4.0, which are considered as part of the concept and process of Public Relations Intelligence.

The in-depth analysis of co-occurrences in the third phase of research, for its part, offered an interesting tree of neighbouring relations illustrated in Fig. 3:

The results shown in Fig. 3 illustrate the consensus reached by the participating experts. As can be observed, they share a critical view of dehumanized consumer relationships and their association with the concepts of technology 4.0 and economy 4.0, in turn associated with demand management based on disruptive technologies such as blockchain or big data. Similarly, an association emerged between technology 4.0 and communication 4.0. The experts agreed that a communicative paradox exists regarding this association: in principle, better communication would be assumed to be achieved thanks to online interaction and the application of big data. Yet it is not achieved. The experts established that in cases of heavy information loads and scarce communication, a risk arises of losing the relational dimension of active listening arises. This would explain, based on a critical view, the clear and robust convergence, found in the causal relationship between communication 4.0 and economy 4.0. Finally, experts understood that public relations 4.0 is part of public relations intelligence and they agreed that this pairing would contribute to developing democratization, opinions and storytelling, thus favouring engagement. These insights are compatible with the results of Arcos (2016), who advanced the need to analyse the two complementary dimensions of "Intelligence-Led Public Relations and Public Relations Intelligence" (p. 269).

In addition, as we will see later, the Delphi panel of experts allowed 
Table 4

Ranking of keywords shaping each process as a vector.

\begin{tabular}{|c|c|c|c|c|c|}
\hline \multicolumn{2}{|l|}{ Engagement } & \multicolumn{2}{|l|}{ Intelligence } & \multicolumn{2}{|l|}{ Tools } \\
\hline Interactivity & 0.846343696117 & value-added & 0.885776758194 & algorithms & 0.880989134312 \\
\hline dialogic & 0.840941727161 & decision & 0.858555436134 & techniques & 0.873414695263 \\
\hline public organization & 0.838465809822 & strategic_planning & 0.841849207878 & computer-based & 0.856003880501 \\
\hline public_engagement & 0.825299918652 & threats & 0.837947905064 & application & 0.843149185181 \\
\hline relatedness & 0.8213134408 & tools & 0.832234025002 & deconstructing & 0.834619581699 \\
\hline involvement & 0.820019841194 & process & 0.812344908714 & apis & 0.832558393478 \\
\hline organization- & 0.819056868553 & up-to-date & 0.799468994141 & methods & 0.832234025002 \\
\hline public_relationships & & analytics & 0.766947090626 & algorithmic & 0.830311238766 \\
\hline empowerment & 0.818176269531 & gathering & 0.751248860359 & automated & 0.827923417091 \\
\hline anticipation & 0.755295693874 & disseminates & 0.116014647484 & analytics & 0.821899354458 \\
\hline participatory & 0.735386967659 & & & & \\
\hline
\end{tabular}

Table 5

Ranking of keywords shaping "automation" and "anticipation" as vectors.

\begin{tabular}{llll}
\hline Automation & & Anticipation & \\
\hline newest & 0.866694927216 & reflection & 0.906183362007 \\
ever-increasing & 0.859624862671 & reflexivity & 0.878478884697 \\
industry-specific & 0.857137680054 & deliberative & 0.876652359962 \\
data-intensive & 0.853706479073 & inclusion & 0.874396562576 \\
advanced & 0.852863550186 & governance & 0.864864349365 \\
bia & 0.850883185863 & constructive & 0.862911760807 \\
bpr & 0.849487304688 & institutionalisation & 0.856473743916 \\
proficiency & 0.84844237566 & deliberation & 0.851648926735 \\
tdm & 0.847041845322 & responsiveness & 0.847873747349 \\
architectural & 0.844620049 & multi-level & 0.837726354599 \\
\hline
\end{tabular}

the generation of concepts for Economy 4.0, Public Relations 4.0 and Public Relations Intelligence.

\section{Discussion and conclusions}

The results of the triangulation method helped to answer the study's research questions, allowing the identification of three disruptive processes with a notable impact on public relations: automation, anticipation and intelligence. This leads us to believe that technological disruption generates disruptive processes in public relations, giving rise to a binomial concept of Public Relations-Strategic Intelligence, where cross-disciplinary debates emerge and enrich new discourses on the future of public relations (Arcos, 2016; Roper \& Hurst, 2019; Torres \& Santa, 2018; Kuteynikov et al., 2019). In addition to referring to the synergies of two disciplines that are constantly being reconfigured (López et al., 2019; McKie \& Munshi, 2007), both terms share the anticipatory function of preventing risks, conflicts and even hybrid threats (Aldrich \& Herker, 1977; Arcos, 2018; Galloway, 2013; Macnamara, 2017; McKie \& Heath, 2016; Turk, 1986).

As Hussein (2009) explains, this type of triangulation makes it possible to overcome social sciences' traditional methodological biases, while helping to improve the degree of internal and external validity of the analysed data set (Alzás \& Casa, 2017). Furthermore, in our case, as suggested by Gaitán and Lozano (2013), this "multiple operationalism as a research strategy" (p. 599) helped to learn more about the complexity of the object of study. In a complementary way, and in accordance with works such as those of Ponti and Domingo (2014), or Wakefield and Watson (2014), the Delphi method of research was applicable to the public relations industry in the technological context, with the aim "to falicitate formal discussion among selected experts in a given domain around a particular topic"(p. 577). This is all the more relevant when ambiguous and complex issues are analysed for which interviews and questionnaires are insufficient, as in our case, and where a critical reflection by multidisciplinary experts is essential to reach a consensus on Public Relations Intelligence.

In this way, linking strategic intelligence to the concept of public relations in this context of technological revolution also has major implications for public relations, regarding the configuration of multiple or holistic public relations intelligences suggested by authors such as McKie et al. (2016) or Macnamara (2016a,2016b). Specifically, the social function of public relations prevails in universe 4.0 thanks to the critical intelligence of public relations that monitors, observes and prevents not only conflicts in a given organisation, but also perverse consequences in society (Roper \& Hurst, 2019). It also prevails due to the competitive intelligence of public relations within the framework of economy 4.0, which reconfigures the conversations of the new modes of

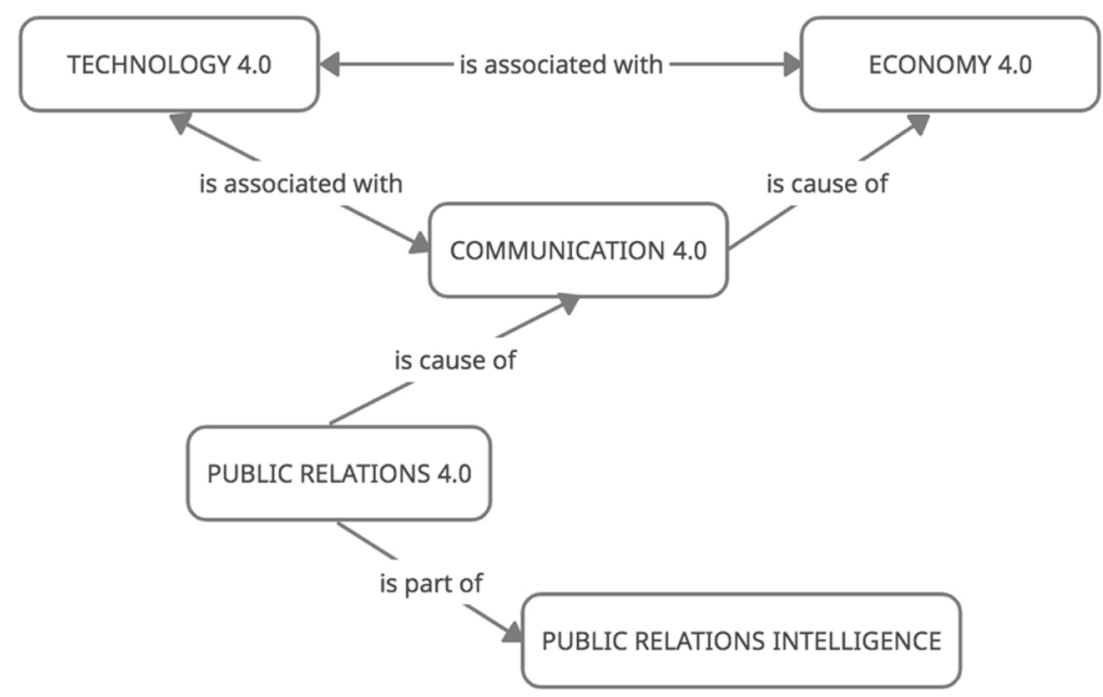

Fig. 2. The experts' vision on the conceptual delimitations and causal links or relationships of belonging of the public relations concept in universe 4.0. 


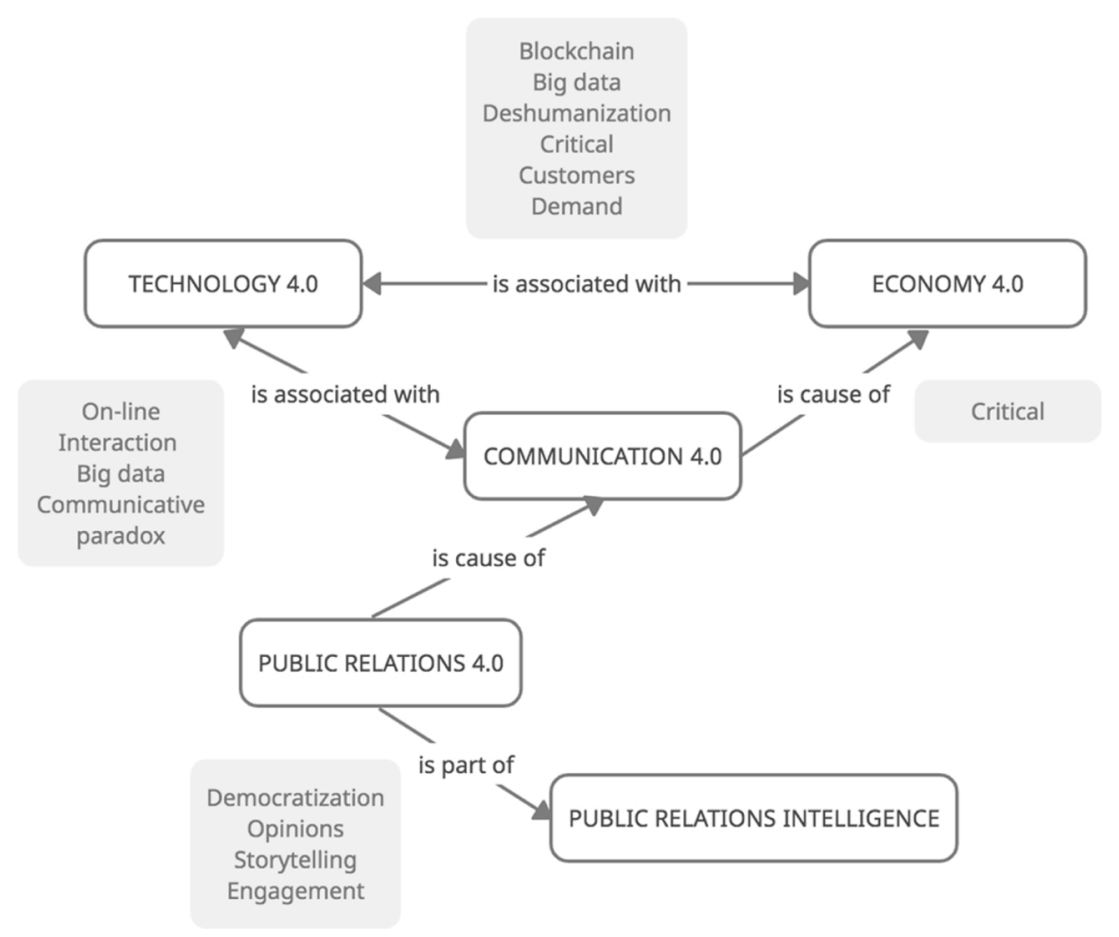

Fig. 3. Common links, including the critical perspective.

relationship mediated by technology (Kuteynikov et al., 2019). Finally, it prevails thanks to the transdisciplinary intelligence of public relations that helps to understand the disruptive processes as well as the digital divides and to enhance technological exploitation based on the social appropriation of scientific knowledge (UN, 2019).

In this way, this study contributes a new approach to modern public relations praxis in the sense of today's terminological hybridisation. Public relations can now explore- beyond its online communication services, social media management or its commercial applications of artificial intelligence-modern intersections with other disciplines within the framework of its management processes. Public relations now dispose of margins of openness and dialogue that enables it to benefit from the technological potential available, beyond the echoes of its campaigns. This new reach justifies our efforts to seek a definition of Public Relations Intelligence and propose a hybridising with the field of artificial intelligence, in line with the arguments of Kent and Saffer (2014) and their emphasis on the risks of technology in the practice of public relations: "we are managers of communication, organizational counsellors, protectors of organizational reputation and image, cultivators of relationships, environmental scanners, and dozens of other things, but not corporate tweeters, marketing managers, chief bloggers, or sales support staff. Let us reclaim public relations technology research and begin asking and answering more substantive and complex questions" (p. 575).

Undeniably, modern public relations are committed to preserving, in their decision-making, the components of anticipation, networking, as well as building stakeholder and public engagement based on dialogue and trust. However, one can observe that a strong trend towards technology-mediated relationships is emerging, which, supported by the sophistication of algorithms, may run the risk of depersonalisation and of losing its essence: that is, conflict prevention and building relational capital for organisations. In line with Beiner (2019b), Arcos (2016) and 2018) and Carriço (2019), we wish to reiterate that the human factor requires special skills in this new technological scenario, combining informative, relational and technical capabilities that allow us to efficiently exploit the value of data to build productive relationships in troubled times.
In fact, some works adopt a critical and ethical perspective, claiming that technology should play a mediating role in order to ensure a responsible management of data and artificial intelligence in public relations. This means that irreplaceable human elements exist in the praxis of public relations. Adding, however, the function of technological surveillance to environment monitoring and analysis can bring a differential advantage to public relation interventions, based on the ability to anticipate and automate its management, encouraging, in turn, a new definition of public relations intelligence resulting from Delphi.

Consequently, the discussion enables to answer the research questions raised in the study. Revolution 4.0 has significant implications regarding the social and practical role of public relations in raising the challenge of multiple intelligences from a contextual and interdisciplinary perspective (Heath, 2006; L'Etang, 2008; McKie et al., 2016). This allows the management of knowledge in a transdisciplinary manner, giving meaning to the construction of the Public Relations-Strategic Intelligence binomial concept as a field of study and expression of the new way of managing relationships and engagement. It also allows benefitting from the past, present and future of both disciplines. In this way, this study permitted the reaching of a consensus regarding the definition of the following terms:

- Economy 4.0: which refers to organisational digitalisation processes, process automation, mass data analysis (e.g. Big data, data mining), disintermediation and personalised attention mediated by technology, in order to enhance decision-making in efficient resource management and profitability.

- Public Relations 4.0: which involves a new way of leading relations based on Economy 4.0 tools, function categorisation and proposal of competent relational processes in order to deal with indirect links through channels which have become processing networks.

- Public Relations Intelligence: understood as function categorisation and the establishment of Informational and relational processes adapted to the development of organisational intelligence, based on the ability to prevent problems through research (both internal and in the organisation's environment) and the proactive, strategic and ethical management of data and information extracted from specialised analysis (SWOT, EPISTLE, 
etc.) in combination with technological surveillance, to strengthen decision-making in strategic communication and increase the impact in terms of engagement with stakeholders.

In this way, the findings of this work show how concepts related to data, technology and engagement emerge as inter-disciplinary intersections to face disruptive processes in the practice of PR in universe 4.0. These disruptive processes in public relations focus on semantic conceptualisations such as intelligence, engagement and automation or anticipation, which are consistent with both essential principles of public relations in the digital era (Macnamara, 2016b,2016b; Galloway \& Swiatek, 2018) and with disciplines related to intelligence (Maccoby, 2001; Maymand et al., 2015; Degerstedt, 2015; Vriens \& Søilen, 2014). However, to overcome the methodological limitations of computational linguistic studies (Pérez \& Moreno, 2009), this study raises the need, in future research, to examine its relevance based on practical evidence, by adapting emerging methods such as netnography to improve our understanding of all the organizational stakeholders who take part in online communities (Toledano, 2017:598).

In this sense, the main findings suggest that a -still immatureresearch field is emerging between strategic intelligence and public relations already immature (Arcos, 2016; Galloway \& Swiatek, 2018; McKie \& Heath, 2016; McKie et al., 2016; Panda et al., 2019; Roper, 2016; Santa et al., 2018;), which highlights those processes as common topics. Strategic intelligence is, however, under researched in the field of public relations, especially from a critical and reflexive perspective.

To conclude, the theoretical framework, conceptual dimension and multidisciplinary criticism proposed in the present study appear to support that the Public Relations-Strategic Intelligence binomial concept represents a strategic driver to face future public relations challenges.

\section{Applications and implications of this work}

Despite its limitations, this study invites us to reflect in a critical and transdisciplinary way on the absolute necessity of transforming the social function of public relations in response to the exponential impact of disruptive technologies. In fact, the study's first implication is that we need to change our vision when conceptualising the practice of public relations within these disruptive technological contexts. We must broaden our perspective, take into consideration hybrid concepts such as the Public Relations-Strategic Intelligence binomial, as well as new lines of research focused on how these incipient and complex, technologymediated forms of relationships are configured. Indeed, virtual-human boundaries are fading away in the light of demands for an increasingly ethical and analytical role regarding the beneficial use of emerging conversational technologies such as chatbots, smart assistants or the long-awaited cognitive intelligence. Therefore, this work points to the strategic role of public relations professionals in this context and how this role should be enacted.

The boards of directors of large corporations, as well as governance actors, have on their agenda priorities such as: the organization's digitization, the collection of massive data from potential consumers and de facto social network presence as clear evidence of public visibility. In this context of action, Kent and Saffer (2014) attribute to" managers of communication, organizational counsellors, protectors of organizational reputation and image, cultivators of relationships" the task of "asking and answering more substantive and complex questions" (p. 575), thereby defining the analytical and ethical role of public relations professionals or departments, Such a concern implies that the public relations figure should seize the opportunity to take advantage of the potential offered by strategic intelligence in organizations. Examples of benefits would be: reducing the confusion of our new informational era, overshadowed by the risks of fake news (Arcos, 2018), or the contradictions arising from the implementation of artificial intelligence (Galloway \& Swiatek, 2018; Panda et al., 2019; Pedreño, 2017;
Sebastião, 2020; Zerfass et al., 2020); or strengthening the processes of active listening, decision-making and anticipating changes. Furthermore, as pointed out by Falcão et al. (2020), this field of application is all the more relevant to address the problems of social appropriation of scientific knowledge, including challenges such as maximising the social impact of large research and innovation projects and the public funding of science. One illustration is how the European Union is pursuing its research and innovation framework programmes. Such programmes reflect how bringing science closer to citizens, and making it understandable has become a strategic priority for the competitiveness and future of the continent.

In this line, regarding the work of public relations on co-orientating actors in a relationship, such an ethical and analytical stance supports a critical-constructive approach. As we analysed in the Delphi semantic map of co-occurrences, public relations 4.0 is also part of the intelligence of public relations, taking into account the need for hybridization and openness which was pointed out in this work. The latter demands persuasive communication, that is performed with clarity, conciseness and responsibility so as to generate trustworthy and inclusive customer experiences.

To finish, this work sought to contribute to our understanding of the new function of public relations as a form of corporate conscience in a technological context, shaped towards maximising human potential in the face of technological determinism. For this reason, as stated by Arief and Gustomo (2020), it is imperative that public relations professionals become aware of the hybrid nature of universe 4.0, in which human potential can be maximised by technology, while bearing in mind that technologies are created themselves by human beings.

\section{Declaration of Competing Interest}

There is no conflict of interest for the authors of this work.

\section{References}

Adidam, P. T., Gajre, S., \& Kejriwal, S. (2009). Cross-cultural competitive intelligence strategies. Marketing Intelligence \& Planning, 27(5), 666-680.

Aguilar, F. J. (1967). Scanning the business environment. New York: McMillan.

Aguirre, J. (2015). Inteligencia estratégica: Un sistema para gestionar la innovación. Estudios Gerenciales, 31(134), 100-110.

Ahmad, Z. A. (2019). Embracing social media: The change and disruption to public relations practices in Malaysia. Juornal Komunikasi: Malaysian Journal of Communication, 35(1), 319-337.

Ahmad, A., Amirkhani, A. H., Ezzat, A. A. P., \& Hozori, M. J. (2018). Identifying and describing sub-processes in the strategic intelligence process by qualitative content analysis in an inductive way. Journal of Intelligence Studies in Business, 8(1), 16-24.

Aldrich, H., \& Herker, D. (1977). Boundary spanning roles and organization structure. The Academy of Management Review, 2(2), 217.

Alzás, T., \& Casa, L. M. (2017). La evolución del concepto de triangulación en la investigación social. Pesquisa, 5(8), 395-418. Retrieved from https://editora.sepq. org.br/index.php/rpq/article/view/95.

Arcos, R. (2016). Public relations strategic intelligence: Intelligence analysis, communication and influence. Public Relations Review, 42(2), 264-270.

Arcos, R. (2018). Hybrid CoE Post-event analysis of the hybrid threat security environment: Assessment of influence communication operations. Retrieved from: https://www. hybridcoe.fi/publication-tags/strategic-analysis/.

Arief, N. N., \& Gustomo, S. (2020). Analyzing the impact of Big Data and Artificial Intelligence on the Communication Profession: A case study on public relations (PR) practitioners in Indonesia. International Journal on Advanced Science, Engineering and Information Technology, 10(3), 1066-1071.

Bachmann, P. (2019). Public relations in liquid modernity: How big data and automation cause moral blindness. Public Relations Inquiry, 8(3), 319-331.

Becerril, A. A., \& Ortigoza, S. (2018). Habilidades tecnológicas y realidades del derecho informático empresarial. Revista IUS, 12(41).

Beiner, F. (2019a). Will "Public relations manager (PR manager)" be replaced by robots? Retrieved from Replaced by Robot: https://www.replacedbyrobot.info/60457/pub lic-relations-manager-pr-manager.

Beiner, F. (2019b). Will "Director of Public Relations" be replaced by robots?. Retrieved from (February 25, 2021) https://www.replacedbyrobot.info/471/director-of-publ ic-relations.

Boder, A. (2006). Collective intelligence: A keystone in knowledge management. Journal of Knowledge Management, 10(1), 81-93.

Boynton, L. A. (2006). What we value: A Delphi study to identify key values that guide ethical decision-making in public relations. Public Relations Review, 32(4), 325-330. 
Caldiero, C. (2016). Neo-PR: Public relations in a postmodern world. Nwe York, NY: Peter Lang Publishing.

Calof, J. L., Richards, G., \& Santilli, P. (2017). Insight through open intelligence. Journa of Intelligence Studies in Business, 7(3), 62-73. Retrieved from https://ojs.hh.se/index. $\mathrm{php} / \mathrm{JISIB} / \mathrm{article} / \mathrm{view} / 245$.

Calof, J., Wright, S., \& Dishman, P. (2008). Competitive intelligence: A multiphasic precedent to marketing strategy. European Journal of Marketing, 42(7/8), 766-785.

Camarinha, L. M., Fornasiero, R., \& Afsarmanesh, H. (2017). Collaborative networks as a core enabler of industry 4.0. In FIP advances in information and communication technology, 506 pp. 3-17).

Capatina, A., Bleoju, G., Yamazakib, K., Amazakib, K., \& Nistor, R. (2016). Cross-cultural strategic intelligence solutions for leveraging open innovation opportunities. Journal of Intelligence Studies in Business, 6(3), 27-38.

Carriço, G. (2018). The EU and artificial intelligence: A human-centred perspective. European View, 17(1), 29-36. https://doi.org/10.1177/1781685818764821.

Castillo, A., \& Xifra, J. (2006). Investigación bibliométrica de las tesis doctorales españolas sobre relaciones públicas (1965-2005). Anàlisi: Quaderns de Comunicació i Cultura, 34, 141-161.

Chávez, B. L., \& Yamamoto, J. M. (2014). Análisis de contenido y lingüística computacional: Su rapidez, confiabilidad y perspectivas. Anales de Psicología, 30(3), $1146-1150$.

Choo, C. W. (2002). Information management for the intelligent organization: The art of scanning the environment. Medford: Information Today. Inc.

Cohen, C. (2013). Business intelligence: The effectiveness of strategic intelligence and its impact on the performance of organisations. Hoboken: NJ: Wiley-ISTE.

Crumpton, M. A. (2015). Strategic human resource planning for academic libraries: Information, technology and organization. New York, NY: Chandos Publishing.

Davenport, T. H. (2018). From analytics to artificial intelligence. International Journal of Business Analytics and Intelligence, 1(2), 73-80.

Degerstedt, L. (2015). Social competitive intelligence: Socio-technical themes and values for the networking organization. Journal of Intelligence Studies in Business, 5(3), 5-34. Retrieved from https://ojs.hh.se/index.php/JISIB/article/view/135.

Edwards, L., \& Hodges, C. E. M. (2011). Public relations, society and culture: Theoretical and empirical explorations. Abingdon, UK: Routledge.

Eggensperger, J., \& Redcross, N. R. (2018). Data-driven public relations research: 21st century practices and applications. London, UK: Taylor and Francis.

Erkul, M., Yitmen, I., \& Celik, T. (2016). Stakeholder engagement in mega transport infrastructure projects. Procedia Engineering, 161, 704-710. https://doi.org/ 10.1016/j.proeng.2016.08.745.

Fahey, L., \& Narayanan, V. K. (1986). Macroenvironmental analysis for strategic management. South-Western.

Falcão, P., Ramalho, N., \& Nobre, M. (2020). Stakeholder management: The new role of business diplomacy. The Journal of Business Strategy. https://doi.org/10.1108/JBS01-2020-0016. Vol. ahead-of-print No. ahead-of-print.

Fantinelli, S., \& Sivilli, D. F. (2015). Open source intelligence's methodology applied to organizational communication. Mediterranean Journal of Social Sciences, 6(2), 233-239. Retrieved from.

Fleisher, C. S., \& Bensoussan, B. E. (2007). Business and competitive analysis: Effective application of new and classic methods. Financial Times Press.

Gaitán, J. A., \& Lozano, C. (2013). Triangulación en el análisis de la representación social del cambio climático. Investigar la comunicación hoy. Revisión de políticas científicas y aportaciones metodológicas: Simposio internacional sobre política científica en comunicación, 3, 599-614. Retrieved from http://uvadoc.uva.es/handle/10324/301

Galloway, C. J. (2013). Deliver us from definitions: A fresh way of looking at public relations. Public Relations Inquiry, 2(2), 147-159.

Galloway, C., \& Swiatek, L. (2018). Public relations and artificial intelligence: It's not (just) about robots. Public Relations Review, 44(5), 734-740.

García, M., \& Suárez, M. (2013). El método Delphi para la consulta a expertos en la investigación científica. Revista Cubana de Salud Pública, 39(2), 253-267.

Godin, B. (2006). On the origins of bibliometrics. Scientometrics, 68(1), 109-133.

Gregory, A. (2010). Planning and managing public relations campaigns: A strategic approach (3 ed.). Kogan Page Ltd.. PR in Practice Series.

Gregory, A., \& Halff, G. (2020). The damage done by big data-driven public relations. Public Relations Review, 46(2), Article 101902. https://doi.org/10.1016/j. pubrev.2020.101902.

Ha, J. H., \& Boynton, L. (2014). Has crisis communication been studied using an interdisciplinary approach? A 20-year content analysis of communication journals. International Journal of Strategic Communication, 8(1), 29-44.

Harrysson, M., Métayer Estelle, \& Sarrazin. (2012). How 'social intelligence' can guide decisions. Retrieved December 6, 2018, https://www.mckinsey.com/industries/h gh-tech/our-insights/how-social-intelligence-can-guide-decisions.

He, W., Wu, H., Yan, G., Akula, V., \& Shen, J. (2015). A novel social media competitive analytics framework with sentiment benchmarks. Information \& Management, 52(7), 801-812. https://doi.org/10.1016/J.IM.2015.04.006.

Heath, R. L. (2006). Onward into more fog: Thoughts on public relations' research directions. Journal of Public Relations Research, 18(2), 93-114.

Heath, D., Singh, R., Ganesh, J., \& Kroll-Smith, S. (2013). Exploring strategic organizational engagement in social media: A revelatory case. Thirty-fourth international conference on information systems (pp. 1-15).

Hernández, R., \& Mendoza, C. P. (2018). Metodología de la Investigación. Las rutas cuantitativa, cualitativa y mixta. Mexico: McGraw Hill.

Heuer, R. J., \& Pherson, R. H. (2015). Técnicas analiticas estructuradas para el análisis de inteligencia. Madrid: Plaza y Valdés.
Hussein, A. (2009). The use of Triangulation in Social Sciences Research: Can qualitative and quantitative methods be combined? Journal of Comparative Social Work, (1), $1-12$.

Jelen, A. (2017). Engagement in public relations discipline: Themes, theoretical perspectives and methodological approaches. Public Relations Review, 43(5), 934-944. https://doi.org/10.1016/j.pubrev.2017.04.002.

Jiménez, D. (2016). Beyond mere information transfer: The importance of a relationa approach to market-related internal communication. Journal of Public Relations Research, 28(5-6), 268-281.

Kent, M. L., \& Saffer, A. J. (2014). A Delphi study of the future of new technology research in public relations. Public Relations Review, 40(3), 568-576.

Kim, S.-Y., Choi, M.-I., Reber, B. H., \& Kim, D. (2011). Tracking public relations scholarship trends: Using semantic network analysis on PR Journals from 1975 to 2011. Public Relations Review, 40(1), 116-118. https://doi.org/10.1016/j pubrev.2013.11.017.

Kovacs, O. (2018). The dark corners of industry 4.0 - Grounding economic governance 2.0. Technology in Society, 55, 140-145.

Kuosa, T. (2011). Different approaches of pattern management and strategic intelligence. Technological Forecasting and Social Change, 78(3), 458-467.

Kuteynikov, D., Izhaev, O., Lebedev, V., \& Zenin, S. (2019). Transformation of public relations in the conditions of technological revolutions: Technology and innovation. International Journal of Recent Technology and Engineering, 8(2), 3964-3971.

L'Etang, J. (2008). Public relations: Concepts, practice and critique. London, UK: SAGE Publications.

Leonhard, G. (2017). Tecnologia versus Humanidade. O confronto futuro entre a Máquina e o Homem. Lisboa: Gradiva.

Liebowitz, J. (2006). Strategic intelligence: Business intelligence, competitive intelligence, and knowledge management.

Lim, K. (2016). Big data and strategic intelligence. Intelligence \& National Security, 31(4), 619-635.

Lombardero, L. (2015). Problemas y retos de gestión empresarial en la economía digital: estudio comparado y sistémico de competencias directivas. España: Universidad Camilo José Cela.

Long, J. C. (1924). Public relations: A handbook of publicity. New York: McGraw-Hill.

López, J. R., Otegi, J. R., Porto, I., \& Cobo, M. J. (2019). 30 years of intelligence models in management and business: A bibliometric review. International Journal of Information Management, 48, 22-38.

Maccoby, M. (2001). The human side: Successful leaders employ strategic intelligence. Research-Technology Management, 44(3), 58-60.

Maccoby, M., \& Scudder, T. (2011). Strategic Intelligence: A conceptual system of leadership for change. Performance Improvement, 50(3).

Macnamara, J. (2017). Toward a theory and practice of organizational listening. International Journal of Listening, 1-23.

Macnamara, J. (2016b). Multiple intelligences and minds as attributes to reconfigure PR-A critical analysis. Public Relations Review, 42(2), 249-257.

Macnamara, J. (2016a). The work and 'architecture of listening': Addressing gaps in organization-public communication. International Journal of Strategic Communication, $10(2), 133-148$.

Macnamara, J., \& Zerfass, A. (2012). Social media communication in organizations: The challenges of balancing openness, strategy, and management. International Journal of Strategic Communication, 6(4), 287-308.

Madani, F., \& Weber, C. (2016). The evolution of patent mining: Applying bibliometrics analysis and keyword network analysis. World Patent Information, 46, 32-48.

Maier, W., Möhring, H. C., \& Werkle, K. (2018). Tools 4.0 - Intelligence starts on the cutting edge. Procedia Manufacturing, 24, 299-304.

Manías, I., Jin, Y., \& Reber, B. H. (2019). The state of crisis communication research and education through the lens of crisis scholars: An international Delphi study. Public Relations Review, 45(4). https://doi.org/10.1016/j.pubrev.2019.101797, 101797.

Martí, M. A. (2018). Modelos de semántica distribucional. Actas do XIII Congreso Internacional de Lingüística Xeral (pp. 16-22).

Martínez. (2014). Bibliometrics as a tool to map uncharted territory: A study on nonprofessional interpreting. Perspectives. Studies in Translation Theory and Practice, 23 (2), 205-222. https://doi.org/10.1080/0907676X.2015.1010550.

Maymand, M. M., Shayan, A., \& Kashani, M. (2015). The effect of strategic intelligence on the organizational citizenship behavior of the employees of Office of Economic and Financial Affairs of Hormozgan Province. ABER, 13(6), 3871-3884.

McDowell, D. (2009). Strategic intelligence: A handbook for practitioners, managers, and users. London, UK: Scarecrow Press.

McKie, D., \& Heath, R. L. (2016). Public relations as a strategic intelligence for the 21st century: Contexts, controversies, and challenges. Public Relations Review, 42(2), 298-305.

McKie, D., \& Munshi, D. (2007). Reconfiguring public relations: Ecology, equity and enterprise. Abingdon, UK: Routledge.

McKie, D., Xifra, J., \& Lalueza, F. (2016). Introduction to configuring intelligences for 21C public relations. Public Relations Review, 42(2), 243-248.

Míguez, M. I., Baamonde, X. M., \& Corbacho, J. M. (2014). A bibliographic study of public relations in Spanish media and communication journals, 2000-2012. Public Relations Review, 40(5), 818-828.

Miranda, A. (2015). Big intelligence: Nuevas capacidades del Big Data para los sistemas de vigilancia estratégica e inteligencia competitiva. Madrid: Fundación EOI.

Moe, W., \& Schweidel, D. A. (2014). Social media intelligence. Cambridge, UK: Cambridge University Press.

More, E., Probert, D., \& Phaal, R. (2015). Improving Long-term strategic planning: An analysis of STEEPLE factors identified in environmental scanning brainstorms. 2015 Portland International Conference on Management of Engineering and Technology (PICMET), 381-394. 
Morehouse, J., \& Saffer, A. J. (2018). A bibliometric analysis of dialogue and digital dialogic research: Mapping the knowledge construction and invisible colleges in public relations research. Journal of Public Relations Research, 30(3), 65-82.

Morrison, M. (2007). History of PEST analysis. Retrieved from: https://rapidbi.com/the -pestle-analysis-tool/.

Navarro, M., \& Sabalza, X. (2016). Reflexiones sobre la industria 4.0 desde el caso vasco. Ekonomiaz, 86, 142-173.

Osswald, A. (2019). Public relations as a complex decision-based practice. Public Relations Inquiry, 8(3), 265-279.

Panda, G., Upadhyay, A. K., \& Khandelwal, K. (2019). Artificial Intelligence: A strategic disruption in public relations. Journal of Creative Communications.

Pasadeos, Y., \& Renfro, B. (1992). A bibliometric analysis of public relations research. Journal of Public Relations Research, 4(3), 167-187.

Pedreño, A. (2017). La digitalización y la economía global. Visión general. Revistas ICE, 897, 9-22.

Pereira, T., Portilla, I., \& Rodríguez, N. (2019). Big data y Relaciones Públicas. Una revisión bibliográfica del estado de la cuestión. Revista De Comunicación, 18(1). https://doi.org/10.26441/RC18.1-2019-A8.

Perera, R. (2017). The PESTLE análisis. Nerdynaut.

Pérez, C., \& Moreno, A. (2009). Lingüística computacional y lingüística de corpus. Potencialidades para la investigación textual. Teoría y Literatura Artística en la Sociedad Digital: Construcción y Aplicabilidad de Colecciones Textuales Informatizadas (pp. 67-96).

Ponti, E., \& Domingo, D. (2014). Developing Public Relations 2.0: Practitioners' perceptions on the implementation of interactive communication strategies. Public Relations Review, 40(3), 559-561.

Porter, M. E., \& Millar, V. A. (1985). How information gives you competitive advantage. Harvard Business Review, 63(4), 149-160.

Prescott, J. E. (2012). The evolution of competitive intelligence. Revista Inteligência Competitiva, 2(2).

Quintana, E. (2019). La revolución industrial 4.0 necesita formar líderes para innovar, más allá de la publicidad educativa; o, Algunos ejemplos para recurrir a la formación filosófica en la formación de líderes (I). Sincronía, 75, 79-103.

Reinsborugh, M. (2017). Science fiction and science futures: Considering the role of fictions in public engagement and science communication work. Journal of Science and Technology Issue on Information and Communications Technology, 16(4), 1-8.

Richardson, J. (2017). A brief intellectual history of the STEPE model or framework. Retrieved from: https://pages.gseis.ucla.edu/faculty/richardson/STEPE.htm.

Roper, J. (2016). Futures intelligence: Applying Gardner to public relations. Public Relations Review, 42(2), 258-263.

Roper, J., \& Hurst, B. (2019). Public relations, futures planning and political talk for addressing wicked problems. Public Relations Review, 45(5), Article 101828.

Rotolo, D., Rafols, I., Hopkins, M. M., \& Leydesdorff, L. (2017). Strategic intelligence on emerging technologies: Scientometric overlay mapping. Journal of the Association for Information Science and Technology, 68(1), 214-233.

Sabariego, M., Vilà, R., \& Sandín, M. P. (2014). El análisis cualitativo de datos con ATLAS.ti. REIRE. Revista d'Innovació i Recerca En Educació, 7(2), 119-133.

Salminen, V., Ruohomaa, H., \& Kantola, J. (2017). Digitalization and big data supporting responsible business co-evolution. Advances in human factors, business management, training and education (pp. 1055-1067).

Sampieri, R. H., Collado, C. F., \& Lucio, M. P. B. (2014). Metodología de la investigación. Santa Fe, México: McGraw Hill.

San, Y. I., \& Romero, F. I. (2016). Modelos y herramientas para la vigilancia tecnológica. Ciencias de la Información, 47(2), 11-18.

Santa, A., Lorenzo, C., \& Torres, R. M. (2018). Bibliometric analysis to identify an emerging research area: Public relations intelligence-A challenge to strengthen technological observatories in the network society. Scientometrics, 115, 1-24.

Schmidt, E., \& Cohen, J. (2013). The new digital age: Reshaping the future of people, nations and business. London, UK: John Murray.
Sebastião, S. P. (2020). Artificial intelligence in Public Relations? No thank you. Perceptions of European Communication and Public Relations Professionals. Media \& Jornalismo, 36(20), 93-107.

Seitovirta, L. C. (2011). The role of strategic intelligence services in corporate decision making organization and management. Master's thesis. Espo, Finland: Aalto University School of Economics.

Taylor, M., \& Kent, M. L. (2010). Anticipatory socialization in the use of social media in public relations: A content analysis of PRSA's public relations tactics. Public Relations Review, 36(3), 207-214.

Thompson, J. (1967). Organization in action: Social science bases of administrative theory. McGraw-Hill.

Toledano, M. (2017). Emergent methods: Using netnography in public relations research. Public Relations Review, 43(3), 597-604.

Torres, R. M., \& Santa, A. (2018). Relaciones públicas 4.0: Vigilancia tecnológica e innovación relacional en el desarrollo local. Communication Papers. Media Literacy \& Gender Studies, 7(15), 265-285.

Turk, J. V. (1986). Forecasting tomorrow's public relations. Public Relations Review, 12 (3), 12-21.

UN. (2019). Cuestiones de competencia en la economía digital. Ginebra: Comisión de Comercio y Desarrollo Grupo Intergubernamental de Expertos en Derecho y Política de la Competencia.

Valin, J. (2018). Humans still needed; an analysis of skills and tools in Public Relations. Retrieved from: https://newsroom.cipr.co.uk/humans-still-needed-research-projec t-reveals-impact-of-artificial-intelligence-on-public-relations/.

Vargas, P. C., Almendros, C. P., Anke, L. E., \& Valdés, R. T. (2013). Corporate social responsibility in the IBEX 35: A corpus-based study of CSR reports. Procedia - Social and Behavioral Sciences, 95, 612-620.

Voosen, P. (2017). How AI detectives are cracking open the black box of deep learning. Retrieved from: https://www.sciencemag.org/news/2017/07/how-ai-detectives-ar e-cracking-open-black-box-deep-learning.

Vriens, D., \& Søilen, K. S. (2014). Disruptive Intelligence - How to gather Information to deal with disruptive innovations. Journal of Intelligence Studies in Business, 4(3), 63-78. Retrieved from.

Wakefield, R., \& Watson, T. (2014). A reappraisal of Delphi 2.0 for public relations research. Public Relations Review, 40(3), 577-584.

Wiencierz, C., \& Röttger, U. (2017). The use of big data in corporate communication. Corporate Communications an International Journal, 22(3), 258-272.

Wilkesmann, M., \& Wilkesmann, U. (2018). Industry 4.0 - organizing routines or innovations? VINE Journal of Information and Knowledge Management Systems, 48(2), 238-254.

Willis, P. (2016). From humble inquiry to humble intelligence: Confronting wicked problems and augmenting public relations. Public Relations Review, 42(2), 306-313.

Wolf, M., Semm, A., \& Erfurth, C. (2018). Digital transformation in companies Challenges and success factors. Communications in Computer and Information Science, 863, 178-193.

World Economic Forum. (2017). Fourth industrial revolution. Global issue. Retrieved from: https://www.weforum.org/strategic-intelligence/.

Xifra, J. (2011). Manual de relaciones públicas e institucionales. Madrid, Spain: Editorial Tecnos.

Xu, M. (2007). Managing strategic intelligence: Techniques and technologies. New York: Information Science Reference.

Xu, X., Wang, X., Li, Y., \& Haghighi, M. (2017). Business intelligence in online customer textual reviews: Understanding consumer perceptions and influential factors. International Journal of Information Management, 37(6), 673-683.

Zerfass, A., Hagelstein, J., \& Tench, R. (2020). Artificial intelligence in communication management: A cross-national study on adoption and knowledge, impact, challenges and risks. Journal of Communication Management. https://doi.org/10.1108/JCOM10-2019-0137. Vol. ahead-of-print No. ahead-of-print. 